\title{
Застосування системного підходу до визначення ефективності виконання аварійно-рятувальних заходів під час ліквідації надзвичайних ситуацій природного та техногенного характеру
}

\author{
Валентин Романюк * А; Іван Мещеряков А; Олена Андріюк ${ }^{\text {B }}$ \\ А Национальний університет оборони України імені Івана Черняховського, Повітрофлотський проспект, 28, м. Київ-049, 03049, Україна \\ в Національний університет харчових технологій, вул. Володимирська, 68, м. Київ, 01033, Україна
}

Received: July, 2, 2020 | Revised: August 25, 2020 | Accepted: August 31, 2020

DOI: $10.33445 /$ sds.2020.10.4.15

\begin{abstract}
Анотація
У статті наведені результати розробки науково-методологічного системного підходу до оцінювання ефективності організаційно-технічної системи виконання аварійно-рятувальних заходів під час ліквідації надзвичайних ситуацій природного та техногенного характеру в зоні проведення операції Об'єднаних сил. На основі отриманих результатів спостерігається підвищення інтегральної ефективності використання ресурсного потенціалу організаційнотехнічної системи проведення аварійно-рятувальних робіт за рахунок підвищення функціонального (системного) чи відповідного до нього економічного ефекту.
\end{abstract}

Ключові слова: ефективність, корисний ефект, надзвичайна ситуація, ліквідація наслідків, аварійно-рятувальні роботи, організаційно-технічна система.

\section{Постановка проблеми}

Збройна агресія проти України, за наявності на території нашої держави екологічно небезпечних об'єктів (насамперед, атомних електростанцій та великих підприємств хімічної промисловості), проходження через ії територію ряду транспортно-енергетичних коридорів, а також високої щільності населення та значної кількості промислово-міських агломерацій на Донбасі, неминуче призведе до значних негативних наслідків від надзвичайних ситуацій (НС) природного та техногенного походження для всієї Об'єднаної Європи (екологічної, енергетичної та гуманітарної кризи).

При виборі напрямків досліджень, з точки зору розвитку Збройних Сил України в галузі радіаційного, хімічного та біологічного захисту, було прийнято за доцільне обмежитися аналізом загроз, джерелом яких
$€$ радіаційно та хімічно небезпечні об'єкти. Саме вони, виходячи 3 перспективних концепцій збройної боротьби, пов'язаних із створенням систем високоточної зброї і ведення гібридної війни, і особливо - із зниженням запасів зброї масового ураження та загального обсягу озброєння, можуть бути цілями навмисного руйнування в ході ескалації збройного конфлікту на Південному Сході країни.

Значний рівень зношеності об'єктів критичної інфраструктури, зокрема комунального господарства, вплив глобальних змін клімату, недостатня ефективність систем життєзабезпечення збільшують ризик надзвичайних ситуацій природного i техногенного походження, поширення епідемій небезпечних інфекційних хвороб (COVID-19), особливо в зоні проведення ООС.

\footnotetext{
* Corresponding author: здобувач, e-mail: r.valya@gmail.com, ORCID: 0000-0001-7767-2268
} 


\section{Аналіз останніх досліджень та публікацій}

Досвід минулих воєн і локальних конфліктів показує, що економічні об'єкти епізодично піддавалися цілеспрямованій збройній дії [1-3]. В основному, це були паливонасичені об'єкти (колишня республіка Югославія), при ураженні яких спричиняються великі економічні збитки [4; 5]. Така спрямована збройна дія одержала в сучасних умовах практичний розвиток стосовно до інших видів потенційно небезпечних об'єктів.

Таким чином, беручи до уваги принципову можливість застосування ударних засобів та диверсійно-розвідувальних груп (ДРГ) для руйнування означених об'єктів В ході можливого воєнного конфлікту і наслідки цих руйнувань для воєнно-економічного потенціалу країни, для органів державного управління в сфері цивільного захисту виникає необхідність заздалегідь планувати заходи щодо запобігання можливої шкоди.

Крім того, як свідчать факти статистики, в сукупності саме ці об'єкти представляють найбільшу потенційну загрозу для населення України в мирний час. В [6] відмічається, що процент населення України, яке знаходиться в зоні можливого ураження хімічнонебезпечних об'єктів, складає 9\%, вибухо- та пожежонебезпечних - 1\%, в зоні AEC - 61,7\%, загалом по Україні - 71,7\%. Вітчизняний і міжнародний досвід ліквідації аварійна таких об'єктах (Чорнобильська AEC, AEC "Three Mile Island" в США, хімічне підприємство в М. Бхопал, Індія та ін.) підтверджує, що ці аварії дійсно мають макроекономічні наслідки[7].

Імовірність виникнення техногенних НС зростає внаслідок високого рівня зношеності основних фондів, який в промисловості перевищує 48\% (для машин і обладнання 60\%) [8]. При цьому кошти, що виділяються на заходи з попередження та ліквідації наслідків НC дуже обмежені в зв'язку з кризовим становищем в економіці країни.

\section{Постановка завдання}

Метою статті $\epsilon$ розробка науковометодологічного системного підходу до оцінювання ефективності організаційнотехнічної системи виконання аварійно- рятувальних заходів під час ліквідації надзвичайних ситуацій природного та техногенного характеру в зоні проведення операції Об'єднаних сил.

\section{Виклад основного матеріалу}

Зміст та суть ефективності в теоретичних роботах представляють як міру успішності людської діяльності, результати якої визначаються конкретними цільовими завданнями. У практичній діяльності доводиться стикатися 3 великою кількістю різноманітних завдань i, мабуть, такою ж кількістю різноманітних підходів до оцінки ефективності. Описати весь арсенал прикладних методик практично неможливо.

Загальний підхід до визначення ефективності, можна сказати, лежить на поверхні. Термін «ефективність», як вказується у всіх енциклопедичних довідниках, $є$ похідним від латинського слова effektus, що в перекладі означає результат, наслідок яких-небудь причин. Ефективний-відтак, той, що дає ефект.
Звідси ефективність - властивість системи, що приводить до потрібних результатів. Ця термінологічна характеристика відображає разом з тим і смисловий зміст ефективності як категорії, що виражає властивість організаційно-технічних систем у формі «метарезультат».

Слід підкреслити, що в інженерній практиці навіть саме ґрунтовне визначення суті ефективності не $є$ вичерпною характеристикою цього понятя. Потрібне обов'язкове доповнення у вигляді вимірювального механізму, що представляє собою деяку систему показників та правил їх застосування. Така сукупність показників повинна всебічно відображати вирішувану задачу. Щоб врахувати невизначеність, пов'язану 3 
багатоваріантністю процесу i, відповідно, багатозначністю результативності створюваної (вдосконаленої) організаційно-технічної системи, виникає потреба двосторонньої оцінки ефективності.

Перша сторона полягає в дослідженні цільового аспекту ефективності і пов'язана 3 визначенням того, які властивості (параметри) відображають поставлену мету і які їх значення (нормативи) ми хочемо отримати. Відповідну характеристику співставлення «мета - кінцевий результат» зазвичай називають цільовою ефективністю. Цільова ефективність - це кількісна характеристика кінцевого результату iii функціонування і розвитку протягом обумовленого періоду порівняно з цільовим нормативом і витратою ресурсів при заданих характеристиках стану системи і впливу зовнішнього середовища, а також при заданому векторі управління. Таке трактування ефективності, на нашу думку, досить повно відображає наведене вище визначення суті ефективності.

У відповідності з визначенням показник цільової ефективності системи представляється у вигляді [9]:

$$
\mathrm{W}=\mathrm{W}\left(\mathrm{Y}_{\mathrm{K}}, \mathrm{Y}_{\mathrm{H}}, \mathrm{U}_{\mathrm{K}}, \mathrm{U}_{\mathrm{H}}\right),
$$

де $\mathrm{Y}_{\mathrm{K}}-$ можливий або фактично досягнутий корисний ефект (кінцевий результат) функціонування i розвитку організаційнотехнічної системи; $\mathrm{Y}_{\mathrm{H}}-$ необхідний цільовий кінцевий результат функціонування і розвитку організаційно-технічної системи; $U_{\text {K }}$ - фактичні витрати ресурсів на отримання $\mathrm{Y}_{\kappa} ; \mathrm{U}_{\mathrm{H}}-$ мінімально необхідні витрати ресурсів на отримання $\mathrm{Y}_{\mathrm{H}}$.

Показник ефективності у формі (1) може розглядатися одночасно i як критерій ефективності. У літературі нерідко терміни «критерій» і «показник» використовуються як синоніми. Однак таке ототожнення не у всіх випадках допустимо. Критерій обов'язково $€$ основною ознакою організаційно-технічної системи, за яким визначається ступінь досягнення поставленої мети або виділяється найбільш кращий варіант. У відповідності з цим критерій ефективності можна визначити як математичне відношення, що відображає ступінь відповідності показника ефективності встановленому нормативу. У цьому сенсі критерій ефективності може трактуватися як показник, що відображає ступінь відповідності фактичного або можливого рівня ефективності організаційно-технічної

системи нормативному значенню. Зауважимо, що кінцевий результат функціонування технічних систем може відображатися цілим рядом характеристик: показники власне ефекту, надійності та ін. Вимірники витрачених ресурсів також багатомірні. Тому в ряді випадків доцільно мати декілька критеріїв та показників ефективності. Інтегральний критерій оцінки ефективності організаційно-технічної системи буде розписаний у наступному підрозділі.

Стосовно до завдань аналізу ефективності чітко проглядаються два підходи при формуванні критеріїв і показників ефективності: економічний і технічний. При економічному підході всі складові (1.1) зазвичай представляють у вартісному вираженні. Цьому підходу відповідає економічна ефективність систем.

Згідно з визначенням П. Хейне [10], економічна ефективність - «властивість, найбільш послідовно збільшена економістами. Це не повинно дивувати, оскільки ефективність і економічність - майже синоніми. Обидва терміни характеризують результативність використання засобів для досягнення цілей. Отримувати якомога більше з доступних нам обмежених ресурсів - ось що ми маємо на увазі під ефективністю та економічністю».

Технічний підхід відрізняється фізичним представленням цільових завдань. Під ефективністю тут розуміють ступінь пристосованості системи до виконання поставленої мети, тобто в основі виключно цільова сторона функціонування системи.

Друга сторона оцінки ефективності відображає ту обставину, що отримуване при проектуванні значення цільової ефективності (відповідне технічному завданню) може бути досягнуто різними шляхами, тобто за рахунок різноманітних витрат технічних ресурсів. При такому дослідженні, зазвичай, розглядається вся сукупність параметрів систем. Кінцевий результат (задоволення заданої потреби) при 
цьому пов'язується з розглянутою сукупністю параметрів. Цей аспект проектування можна трактувати як задачу забезпечення якості організаційно-технічної системи, оскільки за визначенням: якість об'єкту - це найбільш повна сукупність характеристик об'єкта, що відноситься до його здатності задовольняти встановлені потреби (ISO 8402). Інтегральний показник якості у порівнянні з оцінкою кінцевого результату за своєю суттю $\epsilon$ узагальненою характеристикою ефективності. Цю характеристику зазвичай називають проектною ефективністю. Конкретні показники технічного аспекту ефективності (цільова та проектна ефективність) розглядаються детально в [10]. В подальшому визначимо такий інтегральний показник ефективності в контексті організаційно-технічної системи.

Якщо розглянути проведення пошуковорятувальних робіт під час ліквідації НС з точки зору системного підходу, то за існуючою на сьогодні класифікацією ї̈ можна віднести до складних ситуативних організаційно-технічних систем.

За результатами наукових публікацій вітчизняних та зарубіжних авторів був проведений аналіз проблематики оцінювання ефективності складних організаційно-технічних систем [11-13]. На сьогоднішній день в узагальненому вигляді оцінювання ефективності вирішується головним чином в постановочному аспекті. Особливості вирішення цієї проблеми конкретизуються для кожної предметної галузі людської діяльності.

Як зазначалося вище, ефективність - це здатність організаційно-технічної системи (технічні пристрої + система управління + група людей + людина) створювати інтегральний ефект. Стосовно до управління складною організаційно-технічною системою ефективність $\epsilon$ мірою точності досягнення об'єктом управління очікуваного стану. Очікуваний стан досягається за допомогою параметрів та стандартів управління.

Процеси аварійно-рятувальних робіт в складній організаційно-технічній системі здійснюється за належної взаємодії трьох визначальних його чинників: персоналу системи, засобів пошуку і рятування та забезпечуючих ресурсів (фінансові ресурси, пально-мастильні та інші витратні матеріали). Використовуючи наявні засоби пошуку i рятування (літальні апарати, засоби авіаційнотехнічного забезпечення польотів, засоби телекомунікація, АРМи), персонал системи здійснює діяльність із забезпечення послуг чергування в системі та здійснення АРP[13]. Це означає, що, з одного боку, мають місце затрати живої та матеріалізованої праці, а 3 іншого, - результати діяльності організаційнотехнічної системи проведення аварійнорятувальних робіт (ОТСПАРР). Останні залежать від масштабів застосування засобів аварійнорятувальних, кадрового потенціалу системи, методів управління системою та рівня їі автоматизації.

Ефективність ОТСПАРР - це комплексний результат використання засобів і ресурсів ОТСПАРР й персоналу системи за певний проміжок часу.

Родовою ознакою ефективності (продуктивності) ОТСПАРР може бути необхідність досягнення мети діяльності ОТСПАРР 3 найменшими затратами праці персоналу ОТСПАРР, ресурсів або часу. У кінцевому підсумку змістовне тлумачення ефективності (продуктивності) як економічної категорії визначається об'єктивно діючим законом економії робочого часу.

Процес формування результатів та ефективності аварійно-рятувальних робіт (АРP) (продуктивності системи) показано на мал. 1.
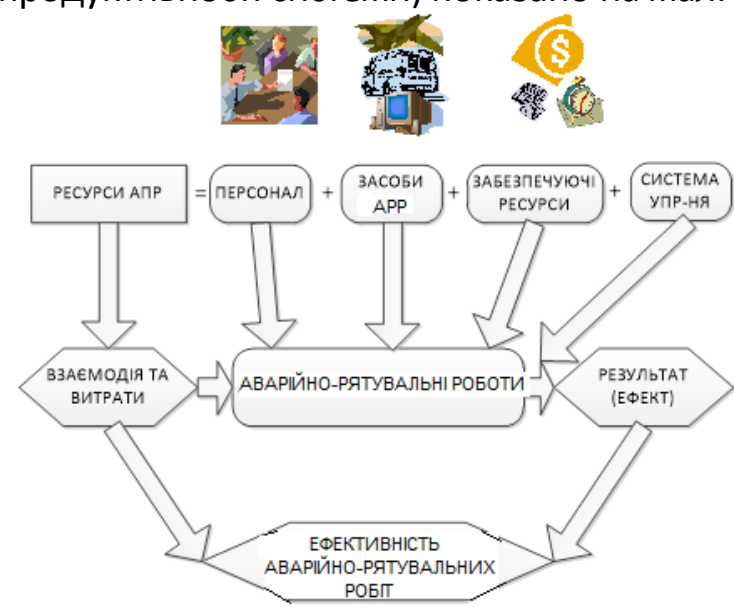

Мал. 1 - Концептуальна схема формуванняефективності ОТСПАРР (продуктивностіскладноїорганізаційнотехнічноїсистеми) 
Сутнісна характеристика ефективності (продуктивності складної організаційнотехнічної системи) знаходить відображення в загальній методології ії визначення, формалізована форма якої має вигляд:

Ефективність (ппродуктиність) $=\frac{\text { Результат }}{\text { Ресурси (ввитрати }}$.

Важливо нагадати, що необхідні для одержання певного результату АРP (діяльності) ресурси розподіляються на одноразові (інвестиційні) та поточні, які витрачаються (щоденні).

Ефективність АРP (продуктивність складної організаційно-технічної системи) має поліморфність визначення й застосування для аналітичних оцінок та управлінських рішень. 3 огляду на це важливим $€$ виокремлювання за окремими ознаками (класифікація) відповідних видів ефективності (продуктивності), кожний з яких має певне практичне значення для ОТСПАРР (табл. 1).

Таблиця 1 -Видова класифікація ефективності діяльності складної організаційно-технічної системи за окремими ознаками

\begin{tabular}{|c|l|}
\hline \multicolumn{1}{|c|}{ Класифікаційна ознака } & \multicolumn{1}{|c|}{ Ефективність } \\
\hline 1. Одержаний результат (наслідки) & $\begin{array}{l}\text { 1. Технічна } \\
\text { 2. Економічна } \\
\text { 3. Соціальна } \\
\text { 4. Екологічна }\end{array}$ \\
\hline 2. Місце одержання ефекту & $\begin{array}{l}\text { 1. Локальна } \\
\text { 2. Глобальна }\end{array}$ \\
\hline 3. Метод розрахунку & $\begin{array}{l}\text { 1. Абсолютна } \\
\text { 2. Порівняльна }\end{array}$ \\
\hline \multirow{2}{*}{ 4. Ступінь збільшення ефекту } & $\begin{array}{l}\text { 1. Первинна } \\
\text { 2. Мультиплікаційна } \\
\text { 3. Синергічна }\end{array}$ \\
\hline \multirow{2}{*}{ С. Структура організації } & $\begin{array}{l}\text { 1. Робочого місця } \\
\text { 2. Окремого підрозділу системи } \\
\text { 2. Системи в цілому }\end{array}$ \\
\hline діяльності & $\begin{array}{l}\text { 1. Науки, техніки і технології } \\
\text { 2. Організаційно-управлінських інновацій } \\
\text { 3. Інвестиційних проектів і програм }\end{array}$ \\
\hline 7. Характер витрат & $\begin{array}{l}\text { 1. Поточних витрат } \\
\text { 2. Одноразових (капітальних) витрат }\end{array}$ \\
\hline \multirow{2}{*}{ 8. Об'єкт оцінки } & $\begin{array}{l}\text { 1. Повна (інтегральна) } \\
\text { 2. Часткова (окрема) } \\
\text { 3. Чинникова (багаточинникова) }\end{array}$ \\
\hline
\end{tabular}

Відповідні види ефективності (діяльності) виокремлюються переважно за різноманітністю одержуваних ефектів (результатів) діяльності системи АРP (організаційно-технічної системи) (табл. 1). У зв'язку з цим виникає необхідність навести сутнісно-змістову характеристику окремих видів ефективності.

Аспект управління організаційнотехнічною системою має найбільшу «значимість» для інтенсифікації кожного реалізуємого способу (технології) застосування системи АРP i, тим самим, підвищення її ефективності.

Об'єктивною оцінкою ефективності системи АРР буде значення відношення рівня системного «ефекту» WS i «витрат» ресурсного потенціалу системи RS, якими цей ефект досягнутий -

$$
E S=\left(\frac{W S}{R S}\right) .
$$

В процесі застосування системи АРP системний ефект «накопичується», тобто стає 
функцією часу -

$$
W S(t), \quad 0 \leq t \leq T S,
$$

де TS - тривалість процесу застосування системи APP.

Використовуючи поняття «потужності» ОТСПАРР як темпу зростання системного ефекту -

$$
m s(t)=\left\{\frac{d w s(t)}{d t}\right\}
$$

одержимо

$$
\text { вираз }
$$

показників

продуктивності $b(t)$ «витратного» ресурсу, що перетворюється у системний ефект (паливномастильні матеріали, енергоносії, витратні матеріали), та продуктивності a(t) «забезпечуючого» ресурсу (персонал, засоби, обладнання, інформація), що перетворює витратний ресурс -

$$
m s(t)=\left(\frac{\partial W S}{\partial r}\right) \times\left(\frac{d r}{d t}\right)=b(t) \times a(t) .
$$

Системний ефект, що досягнутий в процесі застосування системи АРP, буде дорівнювати-

$W S(t=T S)=\int_{0}^{T S} m s(t) \cdot d t=\int_{0}^{T S} b(t) \cdot a(t) \cdot d t .(7)$

Об'єм забезпечуючого ресурсу в процесі застосування системи АРР складе, очевидно -

$$
B S=\int_{0}^{T S} a(t) \cdot d t=\int_{0}^{T S} a\{X(t)\} \cdot d t,
$$

де $X(t)$ - чисельність «одиниць» сил і засобів в ході процесу застосування ОТСПАРР $(0 \leq t \leq T S)$. Якщо вважати коректним припущення про те, що в ході процесу застосування $(0 \leq t \leq T S)$ середня чисельність сил $X S$ і продуктивність «одиниці» сил а(1) практично не змінюються, то формула (7) спрощується -

$B S=\int_{0}^{T S}\{a(1) \cdot X S\} \cdot d t \approx a(1) \cdot X S \cdot T S=A S \cdot T S .(9)$

Середня «групова» продуктивність сил $\mathrm{i}$ засобів буде-

$$
A S=a(1) \cdot X S .
$$

Вважаючи, що завдання системи АРР досягається при рівності його «трудомісткості» $\mathrm{i}$ «трудовитрат» на ії виконання із формули (7) одержимо формулу для «трудовитрат» ресурсної частини ОТСПАРР -

$$
R S=\left\{\frac{B S}{a(1)}\right\}=(X S \cdot T S) .
$$

Звичайно "трудомісткість» об'єму завдання та «трудовитрати» на його виконання оцінюють в «людино-годинах», тому вираз (11) повністю відповідає цій оцінці.

Таким чином, між чисельністю ресурсу XS та тривалістю акту виконання завдання APP TS при потрібному об'ємі і нормативній питомій продуктивності одиниці сил існує «гіперболічна» залежність -

$$
X S=\frac{R S}{T S}
$$

Використання залежності (11) дозволяє математично точно вирішити задачі процесу застосування системи АРР, котрі відносяться до класу задач ресурсної оптимізації.

Відмітимо, що усі показники ефективності системи АРР, які пов'язані з кінцевим результатом ії застосування, прямим чином (функціонально) залежать від «управління» системою. Управління, яке $\epsilon$ «цілеспрямовуючою» функцією, має етапи організаційного управління (розробка плану розподілу витратних ресурсів по завданням $Y$ и плану-сценарію дій сил АРP по застосуванню системи S) та оперативного управління (отримання відповідності процесу накопичення системного ефекту $W S(t)$ планам $Y, S)$. Тоді й ефективність системи APP стає функцією управління системою $(Y, S)$ при «нормативних» значеннях питомих продуктивностей витратних та забезпечуючих ресурсів -

$$
E S(Y, S)=\frac{W S(Y, S)}{R S(Y, S)}
$$

Оскільки досягнення «мети» в процесі застосування системи APP пов'язане 3 потрібним рівнем системного ефекту -

$$
W S(Y, S) \geq W S^{\text {потр }},
$$

то максимізація ефективності по фактору управління $(Y, S)$ досягається мінімізацією «витрат» за рахунок оптимального управління $(Y O, S O)$, тобто -

$$
E S=\frac{W S\left(Y^{o}, S^{o}\right)}{R S\left(Y^{o}, S^{o}\right)} \Rightarrow \frac{W S^{n о m p}}{\min R S} \Rightarrow \max E S .
$$

Таким чином, загальна задача оптимального управління системою АРP має дві наступні інтерпретації. 
Пряма задача - на множині управлінь $\{(Y, S)\}_{\text {пр }}$, кожне з котрих $(Y, S)$ задовольняє обмеження на припустимий чисельний склад сил АPP -

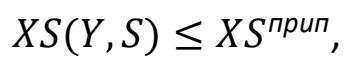

знайти таке (оптимальне) управління (YO,SO), котре мінімізує тривалість акта застосування системи -

$$
\operatorname{TS}\left(Y^{O}, \mathrm{~S}^{O}\right)=\min _{\{(Y, S)\}} T S(Y, S) .
$$

При цьому в процесі застосування досягається максимальна «могутність» OTCПАРP -

$$
M S\left(Y^{O}, S^{O}\right)=\frac{W S^{\text {потp }}}{\min T S}=\max M S,
$$

і максимальна ефективність ОТСПАРР -

$E S\left(Y^{O}, S^{O}\right)_{п р}=\frac{W S^{\text {потр }}}{X S^{\text {пип }} \cdot \min T S}=\max E S$.

Обернена задача - на множині управлінь
$\{(\mathrm{Y}, \mathrm{S})\}_{\text {об }}$, кожне з котрих $(Y, S)$ задовольняє обмеження на припустиму тривалість процесу в процесі застосування -

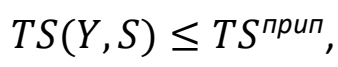

знайти таке (оптимальне) управління $(Y O, S O)$, котре мінімізує склад сил ОТСПАРP -

$$
X S\left(Y^{O}, S^{O}\right)=\min _{\{(Y, S)\}} X S(Y, S) .
$$

При цьому досягається максимальна «продуктивність» сил системи АРP по ефекту-

$$
A S\left(Y^{O}, S^{O}\right)=\frac{W S^{\text {потр }}}{\min X S}=\max A S,
$$

і максимальна ефективність ОТСПАРР в процесі застосування -

$E S\left(Y^{O}, S^{O}\right)_{\text {об }}=\frac{W S^{\text {потр }}}{T S^{\text {пич }} \cdot \min X S}=\max E S$.

відповідний до нього економічний ефект в середньому на 10-30\%. Основним інструментом інтенсифікації виступає «оптимальне управління» системою АРP, котре максимізує її ефективність. ресурсного потенціалу в системний ефект підвищує функціональний (системний) чи
Таким чином, підвищення інтегральної ефективності використання ресурсного потенціалу ОТСПАРР при даній технології інтенсифікації процесу перетворення

\section{Список використаних джерел}

1. Михайлова А.В., Чумаченко С.М. Особливості класифікації джерел небезпеки, що призводять до надзвичайних ситуацій воєнного характеру. Збірник тез доповідей Міжнародної науковопрактичної конференції “Проблеми техногенно-екологічної безпеки: освіта, наука, практика", 21-22 листопада 2019.Національний університет цивільного захисту України, Харків, 2019. С. 51-53.

2. Ірано-іракська війна [Електронний ресурс] - URL: https://uk.wikipedia.org/wiki/\%D0 \%86\%D1\%80\%D0\%B0\%D0\%BD\%D0\%BE\%D1\%96\%D1\%80\%D0\%B0\%D0\%BA\%D1\%81 \%D1\%8C\%D0\%BA\%D0\%B0_\%D0\%B2\%D1\%9 6\%D0\%B9\%D0\%BD\%D0\%B0.

3. Лещенко О. Я. Вплив сучасних воєннополітичних конфліктів на проблематику цивільного захисту: досвід Сирії та України. Вісник Дніпропетровського університету. Дніпропетровськ, 2016. С. 67-80.

4. Скорик А. Б., Воронин В. В., Доска О. М. Аналіз операції "Союзницька сила" і оцінка ії впливу на зміну стратегії оборони США. Збірник наукових праць Харківського університету повітряних сил. Харків, 2009. C. 19-22.

5. Хортов А. А. Роль США в войне НАТО против Югославии [Электронный ресурс]. URL: http://vestnik.yspu.org/releases/2011_1g/2 6.pdf.

6. Кальченко В.М. та ін. Захист населення i територій України від надзвичайних ситуацій. Річна доповідь за 1997 рік. Київ, 1998. 112 c.

7. Звіт про науково-дослідну роботу 
“Експертно-моделююча система ідентифікації зон підвищеної фізико-географічної і техногенної небезпеки та оцінки їх впливу на воєнну безпеку України" (“Природа") (проміжний)/ ННДЦ ОТ і ВБ України. Київ, 2001. 127 c.

8. Бутрим О.В. Розвиток і розміщення потенційно-небезпечних виробництв у містах України та їх вплив на економіку техногенно-екологічної безпеки: дис. ... канд. економ.наук: 08.10.01. НАНУ. Київ, 1998 С. 166-175.

9. Шарий В. І., Невольніченко А. І. Проблематика керування сферою воєнної безпеки. Наука і оборона. Київ, 2000. №1. C.16-21.

10. Хейне П., Боуттке П., Причитко Д. Экономический образ мышления: перевод с английского. Вильямс. Москва, 2007.С. 44. киемодели для оперативного управления региональной безопасностью. Модели и алгоритмы многоуровневого управления эколого-экономическими системами региона. Институт кибернетики имени B.М. Глушкова Академии наук Украины. Киев, 1994. С. 15-22.

12. Чумаченко С.M., Невольніченко А.I. Інтенсифікація ресурсного потенціалу системи воєнно-екологічної безпеки. Збірник наукових праць ННДЦ ОТ і ВБ України. Воєнно-екологічна думка. Київ, 2007. №3.

13. Чумаченко С.М., Лисянский В.А., Шабала В.И. Подходы к оценке интегральной эффективности системы авиационного поиска и спасания. Техногенно-екологічна безпека та цивільний захист. Київ, 2013. №5. C. 138-143.

11. Быченок Н. Н. Экспертнологичес-

\title{
Применение системного подхода к определению
} эффективности выполнения аварийно-спасательных мероприятий во время ликвидации чрезвычайных ситуаций природного и техногенного характера

\author{
Валентин Романюк * А; Иван Мещеряков А; Елена Андриюк ${ }^{\text {В }}$ \\ *Corresponding author: здобувач, e-mail: r.valya@gmail.com, ORCID: 0000-0001-7767-2268 \\ А Национальный университет обороны Украины имени Ивана Черняховского, проспект Воздухофлотский, 28, г. Киев-049, 03049, Украина \\ в Национальный университет пищевых технологий, ул. Владимирская, 68, г. Киев, 01033, Украина
}

\begin{abstract}
Аннотация
В статье приведены результаты разработки научно-методологического системного подхода к оценке эффективности организационно-технической системы исполнения аварийно-спасательных мероприятий при ликвидации чрезвычайных ситуаций природного и техногенного характера в зоне проведения операции Объединенных сил. $\mathrm{Ha}$ основе полученных результатов наблюдается повышение интегральной эффективности использования ресурсного потенциала организационно-технической системы проведения аварийно-спасательных работ за счет повышения функционального (системного) или соответствующего ему экономического эффекта.
\end{abstract}

Ключевые слова: эффективность, полезный эффект, чрезвычайная ситуация, ликвидация последствий, аварийно-спасательные работы, организационно-техническая система.

\section{Application of a systematic approach to determining the effectiveness of emergency rescue measures during the elimination of emergencies of natural and man-made nature}




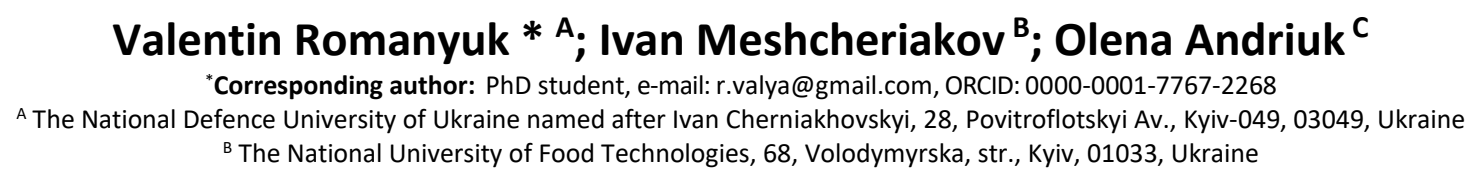

\begin{abstract}
The article presents the results of the development of scientific and methodological system approach to assessing the effectiveness of the organizational and technical system of emergency rescue operations during the elimination of natural and man-made emergencies in the area of the Joint Forces operation. Based on the results obtained is observed increasing the integrated efficiency of the use of the resource potential of the organizational and technical system of emergency rescue operations by increasing the functional (systemic) or corresponding economic effect.
\end{abstract}

Keywords: efficiency, useful effect, emergency situation, liquidation of consequences, emergency rescue works, organizational and technical system.

\title{
References
}

1. MykhaylovaA., Chumachenko S. Osoblyvosti klasyfikatsiy i dzherel nebezpeky, shcho pryzvodyat do nadzvychaynykh sytuatsiy voyennoho kharakteru [Features of the classification of sources of dangerth at lead to military emergencies]. Collection of abstracts of the International scientific-practical conference "Problems of technogenic and ecologica Isafety: education, science, practice", November 21-22, 2019. National University of Civil Defense of Ukraine. Kharkiv, 2019. P. 51-53.

2. Irano-iraks'ka viyna [Iran-IraqWar], [Elektronnyy̆ resurs]. - Retrieved from: https://uk.wikipedia.org/ wiki/\%D0\%86\%D1\%80\%D0\%B0\%D0\%BD\%D0\%BE\%D1\%96\%D1\%80\%D0\%B0\%D0\%BA\%D1\%81\%D1\% 8C\%D0\%BA\%D0\%B0_\%D0\%B2\%D1\%96\%D0\%B9\%D 0\%BD\%D0\%B0.

3. Leshchenko O. Vplyv suchasnykh voyennopolitychny khkonfliktiv na problematyku tsyvil'noho zakhystu: dosvid Syriyita Ukrayiny. [Influence of modern military-political conflicts on the issues of civil defense: the experience of Syria and Ukraine]. Bulletin of Dnipropetrovsk University. Dnipropetrovsk, 2016. P. 67-80.

4. Skoryk A., Voronin V., Doska O. Analiz operatsiyi "Soyuznyts'ka syla" i otsinka yiyi vplyvu na zminu stratehiy i oborony SSHA. [Analysis of Operation Allied Force and assessment of its impact on changing the US defense strategy]. Collection of scientific works of Kharkiv University of the Air Force. Kharkiv, 2009. P. 19-22.

5. Khortov A. Rol' SSHA v voyne NATO protiv Yugoslavii [Role of the USA in the NATO war against Yugoslavia], [Elektronnyy̆ resurs]. -
Retrievedfrom:http://vestnik.yspu.org/releases/2 011_1g/26.pdf.

6. Kalchenko V. etc. Zakhyst naselennya i terytoriy Ukrayiny vid nadzvychaynykh sytuatsiy. [Protection of the population and territories of Ukraine from emergencies]. Annual report for 1997. Kyiv, 1998. 112 p.

7. Zvit pro naukovo-doslidnu robotu "Ekspertnomodelyuyucha systema identyfikatsiyi zon pidvyshchenoyi fizyko-heohrafichnoyi i tekhnohennoyi nebezpeky ta otsinky yikh vplyvu na voyennu bezpeku Ukrayiny" ("Pryroda") (promizhnyy) / NNDTS OT i VB Ukrayiny. [Report on research work "Expert-modeling system for identification of a reasof in creased physicalgeographical and man-made danger and assessment of the irimpacton the military security of Ukraine" ("Nature") (intermediate) / NDC OT and WB of Ukraine]. Kyiv, 2001. 127 p.

8. Butrim 0 . Rozvytok i rozmishchennya potentsiyno-nebezpechnykh vyrobnytstv u mistakh Ukrayiny ta yikh vplyv na ekonomiku tekhnohenno-ekolohichnoy i bezpeky NANU [Development and location of potentially dangerous industries in the cities of Ukraine and their impact on the economy of man-made environmental safety: dis. ... cand. Economics: 08.10.01. NANU]. Kyiv, 1998.P. 166-175.

9. Shary V., Nevolnichenko A. Problematyka keruvanny as feroyu voyennoy i bezpeky. [Problems of military security management. Science and defense]. Kyiv, 2000. №1. P.16-21.

10. Heine P., Bouttke P., Prichitko D. Ekonomicheskiy obraz myshleniya: perevod $\mathrm{S}$ angliyskogo 
[Economic Way of Thinking: Translated from English]. Williams. Moscow., 2007, P. 44.

11. Bychenok N. Ekspertno-logicheskiye modeli dly aoperativnogo upravleniya regional'noy bezopasnost'yu. Modeli i algoritmy mnogourovnevogo upravleniya ekologoekonomicheskimi sistemami regiona [Expertlogical models for operational management of regional security. Models and algorithms for multi-level management of the ecological and economic systems of the region]. Institute of Cybernetics named after V.M. Glushkov Academy of Sciences of Ukraine. Kyiv, 1994. P. 15-22.
12. Chumachenko S., Nevolnichenko A. Intensyfikatsiya resursnoho potentsialu systemy voyenno-ekolohichnoyi bezpeky [Intensification of resource potential of the military-ecological security system]. Collection of scientific works of NNDC OT and VB of Ukraine. Military-ecological thought. Kyiv, 2007. №3.

13. Chumachenko S., Lisyansky V., Shabala V. Podkhody $k$ otsenke integral'noy effektivnosti sistemy aviatsionnogo poiska i spasaniya [Approaches to assessing the integral effectiveness of an aviation search and rescue system]. Technogenic and ecologic safety and civilian zahist. Kyiv, 2013. № 5. P. 138-143. 